\title{
Length-Weight Relationships and Fulton's Condition Factor of Common carp (Cyprinus carpio L., 1758) from Tercan Dam Lake, Eastern Anatolia, Turkey
}

\author{
Özge ZENCIR TANIR ${ }^{1 *}$
}

\author{
${ }^{1}$ Kemah Vocational School, Erzincan Binali Yıldırım University, Erzincan-TURKEY
}

Geliş / Received: 04/03/2020, Kabul / Accepted: 10/07/2020

\begin{abstract}
In this study, length-weight relationships (LWR) and Fulton's condition factor (K) values of totally 190 Common carp, Cyprinus carpio L., 1758 specimens, captured from Tercan Dam Lake between May 2017 October 2017, were examined. Sex composition was $41.58 \%(n=79)$ female and $58.42 \%(n=111)$ male. Female to male sex ratio of the population was found as 1:0.71. Fork length and weight values of overall, female and male specimens ranged from 11.2-55.5 cm/30.2-2860.5 g, 11.2-55.5 cm/30.2-2860.5 g and 12.7-47.5 cm/44.6$1846.9 \mathrm{~g}$, respectively. K values varied between 1.204 and 4.008. The average value of its was calculated as $2.155 \pm 0.041$ for females, $2.138 \pm 0.046$ for males and $2.148 \pm 0.030$ for overall. The LWR were determined $\mathrm{W}=$ $0.0646 * \mathrm{FL}^{2.6613}$ for females, $\mathrm{W}=0.0389 * \mathrm{FL}^{2.8103}$ for males and $\mathrm{W}=0.0528 * \mathrm{FL}^{2.7202}$ for overall. The values of $\mathrm{b}$ was estimated as 2.66 (females); 2.81 (males); 2.72 in overall. According to b value of LWR, the growth of C.carpio was negatif allometric $(\mathrm{b}<3, \mathrm{P}<0.005)$. No information currently exists on the LWR of C.carpio in the Tercan Dam Lake, Eastern Anatolia, Turkey. Therefore, this paper is an important contribution to the fisheries management applications.
\end{abstract}

Keywords: Common carp, Cyprinus carpio, growth parameters, Tercan Dam Lake

\section{Tercan Baraj Gölü 'nde Yaşayan Sazan (Cyprinus carpio L., 1758) Balığının Boy-Ağırlık İlişkisi ve Kondisyon Faktörü}

$\ddot{O} z$

Bu çalışmada, Tercan Baraj Gölü’nden Mayıs 2017-Ekim 20017 tarihleri arasında yakalanan 190 adet sazan balığının (Cyprinus carpio L., 1758) boy-ağırlık ilişkileri ve Fulton's kondisyon faktörü değerleri incelenmiştir. Örneklemin \% 41.58 (n=79)'sını dişiler, \% 58.42 (n=111)'ünü erkekler oluşturmuştur. Populasyonun dişi/erkek oranı 1:0.71 olarak bulunmuştur. Örneklerin çatal boy ve ağırlıkları sırasıyla 11.2-55.5 cm/30.2-2860.5 g, 11.2$55.5 \mathrm{~cm} / 30.2-2860.5 \mathrm{~g}$ and 12.7-47.5 cm/44.6-1846.9 g, olarak bulunmuştur. Kondisyon faktörü değerleri 1.204-4.008. arasında değişmiştir. Ortalama kondisyon faktörü dişiler için 2.155 \pm 0.041 , erkekler için $2.138 \pm 0.046$ ve tüm bireyler için ise $2.148 \pm 0.030$ olarak hesaplanmıştır. Boy-ağırlık ilişkileri dişilerde $\mathrm{W}=$ $0.0646 * \mathrm{FL}^{2.6613}$, erkeklerde $\mathrm{W}=0.0389 * \mathrm{FL}^{2.8103}$ ve tüm bireylerde $\mathrm{W}=0.0528 * \mathrm{FL}^{2.7202}$ olarak tespit edilmiştir. "b" değerleri dişilerde 2.66, erkeklerde 2.81 ve tüm bireylerde 2.72 olarak hesaplanmıştır. C.carpio'nun büyümesi negatiftir $(\mathrm{b}<3, \mathrm{P}<0.005)$. Tercan Baraj Gölü'nde C.carpio' nun boy-ağırlık ilişkisi ve kondisyon faktörü hakkında bilgi bulunmamaktadır. Bu nedenle, bu çalışma, balıkçılık yönetimi uygulamalarına önemli bir katkı sağlayacaktır.

Anahtar Kelimeler: Sazan balığı, Cyprinus carpio, büyüme parametreleri, Tercan Baraj Gölü 


\section{Introduction}

The common carp (Cyprinus carpio) belongs to the Class Osteichthyes (the bony fishes), the order Cypriniformes and the family Cyprinidae, which is considered the largest family of freshwater fish in the world (Anonim, 2020). In Turkey, it has widespread distribution in freshwater ecosystems such as natural lakes, pond, dams lakes and rivers stagnant flowing parts of a large, also rarely inhabits brackish-water environments (Demirkalp, 2007; Saylar and Benzer, 2014).

C.carpio, which is considered to be a very important aquaculture species, has been successfully introduced into most freshwaters because of high growth speed of length and weight, high meat yield, nonselective habitat use, easy production availability in fish farms and tasty meat (Demirkalp, 1992).

In fishery science, fish length can often be measured more rapidly and easily than weight (Kara and Bayhan, 2008). The general lengthweight relationships (LWR) provide a mathematical relationship between the two variables, length and weight, so that the unknown variable can be easily calculated from the known variable (Dar et al., 2012; Sarkar et al., 2012). Condition factor (K) is an expression of relative fatness of fish and generally larger values of $\mathrm{K}$, indicates better condition of the fish. This factor is calculated from the relationship between the weight of a fish and its length, with the intention of describing the "condition" of that individual fish (Froese, 2006).

Length-weight relationships (LWR) are important and have many applications in fish stock assessments, biomass estimations, ecological studies and modeling aquatic ecosystems (Froese, 2006). In addition, the LWR in important in terms of providing for the estimation of weight from the length and the calculation of condition indices as well as providing general information about the morphology of populations in different habitats and their life cycles (Petrakis and Stergiou, 1995; Froese et al., 2011). Condition factor are also important biological parameter as it gives us clear knowledge regarding the maturation and spawning of fish at different body lengths during their life span also estimating the condition at different months and provides information on the physiological state of the fish in relation to its welfare and based on the hypothesis that heavier fish of a given length are in better condition (Bagenal and Tesch, 1978).

The first study on the carp population was started by Numann (1958), and many studies have been made on the length-weight relationship and condition factor regarding C.carpio in dam lakes of different geographic regions of Turkey ( Table 1). However, there is no information available regarding the biological parameter of the common carp population in Tercan Dam Lake. The objective of this study was to investigate and report the first data on length-weight relationship and condition factor of $C$. carpio which is preferred by local people because of having high economical value. Also, the data presented are compared with results from similar studies.

\section{Material and Methods}

\subsection{Description of the study site and data collection}

Tercan Dam Lake is a dam built in Erzincan province on Tuzla stream for the purpose of irrigation and electrical energy production between 1969-1988. It has a surface area of $8.85 \mathrm{~km}^{2}$, a drainage volume of 178 million $\mathrm{m}^{3}$, and an irrigation area of 29725 ha. The geographical location of the study area is as shown in Figure 2. It is located on latitude $39^{\circ} 44^{\prime} 04.30^{\prime \prime} \mathrm{N}, \quad 39^{\circ} 26^{\prime} 26.82^{\prime \prime} \mathrm{E} ; \quad 1448 \mathrm{~m}$ altitude.

A total of 190 specimens of $C$. carpio L., 1758 were colleted from Tercan Dam Lake in May 2017-October 2017 using gillnets of various mesh sizes (20, 30, 40 and $55 \mathrm{~mm}$ ). Fish collected were anesthetized using MS 222, 
preserved in $4 \%$ formaldehyde solution and then transported to the the laboratory for further analysis. The collected specimens of C.carpio (Figure 1) were measured for fork length $(\mathrm{FL}$, in $\mathrm{cm})$ to the nearest millimeter and total weight (W, in $\mathrm{g}$ ) using a digital balance with an accuracy of $0.1 \mathrm{~g}$. Sex was firstly recognised by a macroscope observation of the gonads.

\subsection{Determination of length-weight relationship and Fulton's condition factor}

The length-weight relationship (LWR) were determined for males, females and combined sexes according to equation, $W=a F L^{b}$, where $\mathrm{W}$ was the body weight (g), FL was the fork length $(\mathrm{cm})$, a was the intercept of the regression and $b$ was the regression coefficient (slope) (Bagenal and Tesch, 1978; Ricker, 1975). These parameters were estimated by the least squares regressions method and, then, subjected to logarithmic expression $\quad \log W=\log a+b \log F L$. Standard error was calculated for the slope (b). The hypothesis of isometric growth was tested through the student's t-test, with values of $\mathrm{p}<0.005$ considered significant.

Student's t-test was used for comparison $b$ value obtained in the linear regression with isometric value (Sokal and Rohlf, 1987): $t_{s}=$ $\frac{(b-3)}{s_{b}}$, where $\mathrm{t}_{\mathrm{s}}$ is the $\mathrm{t}$-test value, $\mathrm{b}$ the slope and $S_{b}$ the standard error of the slope (b). The comparison obtained values of t-test with the respective tabled critical values allowed for the determination of the $b$ values statistically significant, and their inclusion in the isometric range $(b=3)$ or allometric range (negative allometric $b<3$, positive allometric $b>3$ ). The degree of correlation between the variables was computed to determine coefficient, $\mathrm{r}^{2}$.

The Fulton's condition factor was computed using the formula as: $K=\left(\frac{W}{L^{3}}\right) X 100$, where $\mathrm{K}$ is the Fulton's condition factor, $\mathrm{W}$ is the body weight $(\mathrm{g})$, and $\mathrm{L}$ is the total length $(\mathrm{cm})$ (Bagenal and Tesch, 1978). Differences between $\mathrm{K}$ values of females, males and combined sex were tested using the student's t-test (Zar, 1999). All statistical analyses were done using MS-Excel and SPSS (version 17.0).

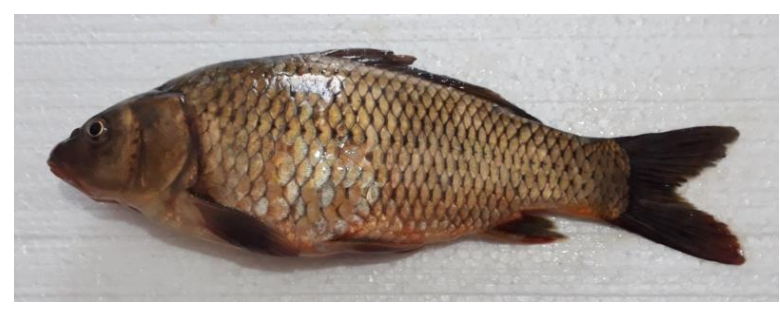

Figure 1. A specimen of Cyrinus carpio collected from Tercan Dam Lake (Photo: Ö.Zencir Tanır)

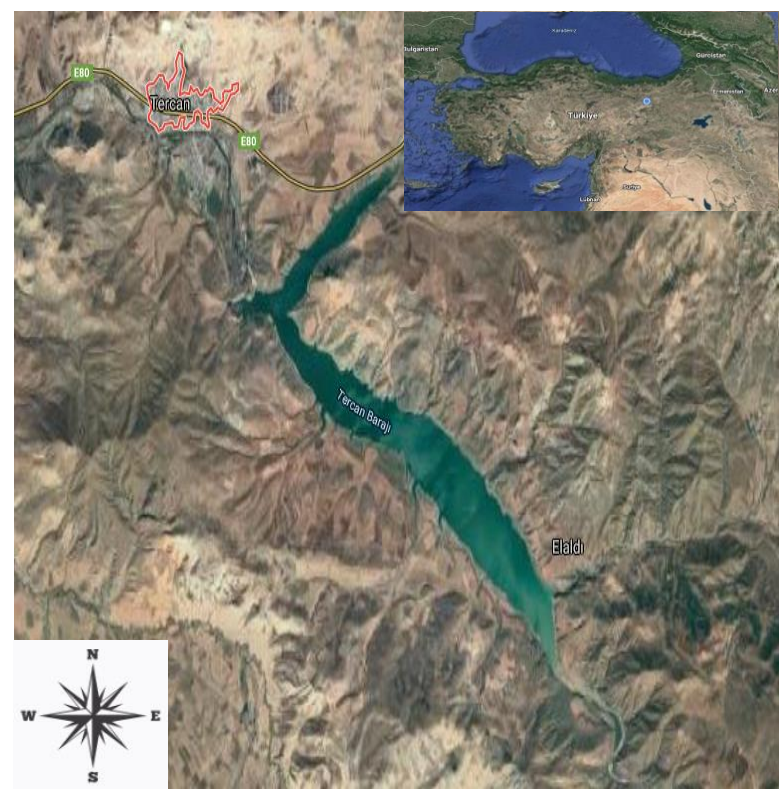

Figure 2. Map of the studying area

\section{Research Findings}

Investigation of 190 specimens revealed that C.carpio population inhabiting the waters of Tercan Dam Lake was composed of $41.58 \%$ $(n=79)$ female and $58.42 \%(n=111)$ male. The sex ratio (female:male) was 1:0.71 in favour of males and this ratio was deviated significantly from 1:1 $(\mathrm{p}<0.05)$. Fork length values of overall, female and male specimens ranged from $11.2-55.5 \mathrm{~cm}, 11.2-55.5 \mathrm{~cm}$ and 12.7-47.5 cm, respectively. Total weight values of overall were $30.2-2860.5 \mathrm{~g}$; of females, 30.2-2860.5 g; and males 44.6$1846.9 \mathrm{~g}$. The growth was negative allometric 
for Tercan Dam Lake population of C.carpio and the $b$ values ranged from 2.6613 to 2.8103 for all three groups: female, male and overall (Table 1). All regression values were found to be significant $(p<0.05)$ and the values of coefficient of determination $\left(\mathrm{r}^{2}\right)$ were greater than 0.97 for all groups. Length-weight relationships for overall, female and male were calculated as $\mathrm{W}=0.0528 * \mathrm{FL}^{2.7202},\left(\mathrm{r}^{2}=\right.$ $0.9725)$ (Figure 3$), \mathrm{W}=0.0646 * \mathrm{FL}^{2.6613}\left(\mathrm{r}^{2}=\right.$ 0.9726 ) (Figure 4) and $\mathrm{W}=0.0389 * \mathrm{FL}^{2.8103}\left(\mathrm{r}^{2}\right.$ $=0.9740)($ Figure 5).

The average value of Fulton's condition factor (K) was calculated $2.155 \pm 0.041$ for females, $2.138 \pm 0.046$ for males and $2.148 \pm 0.030$ for overall. It values also did'nt show significant variations $(\mathrm{p}<0.05)$ for female and male specimens of C.carpio. A geographic comparison concerning the length-weight relationship and condition factor for the species was also made using the results reviewed from previous studies (Table 2)

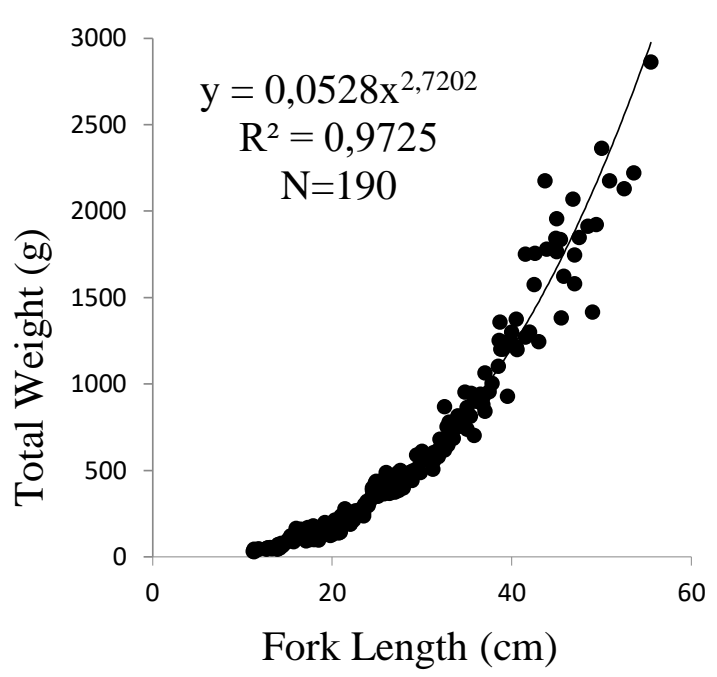

Figure 3. Length-weight relationships of $C$. carpio overall from Tercan Dam Lake, Eastern Anatolia, Turkey

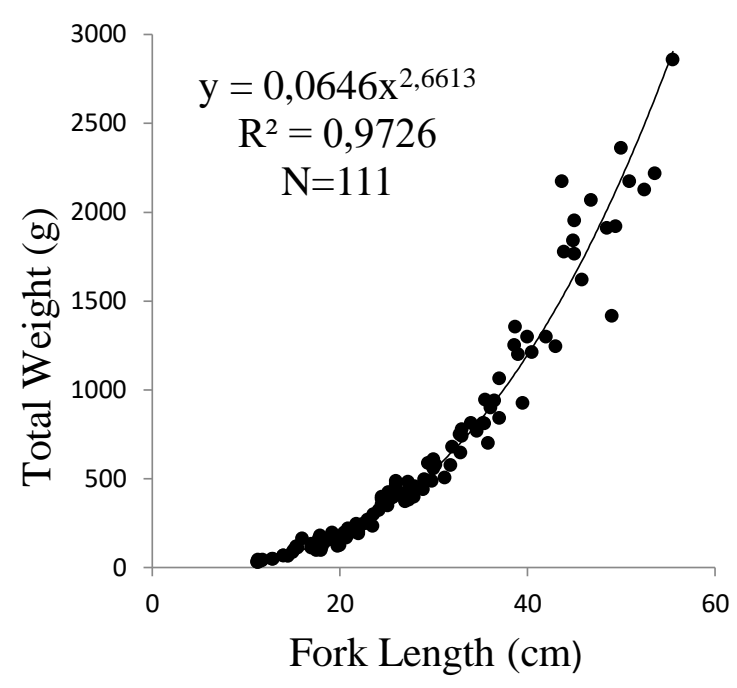

Figure 4. Length-weight relationships of $C$. carpio females from Tercan Dam Lake, Eastern Anatolia, Turkey

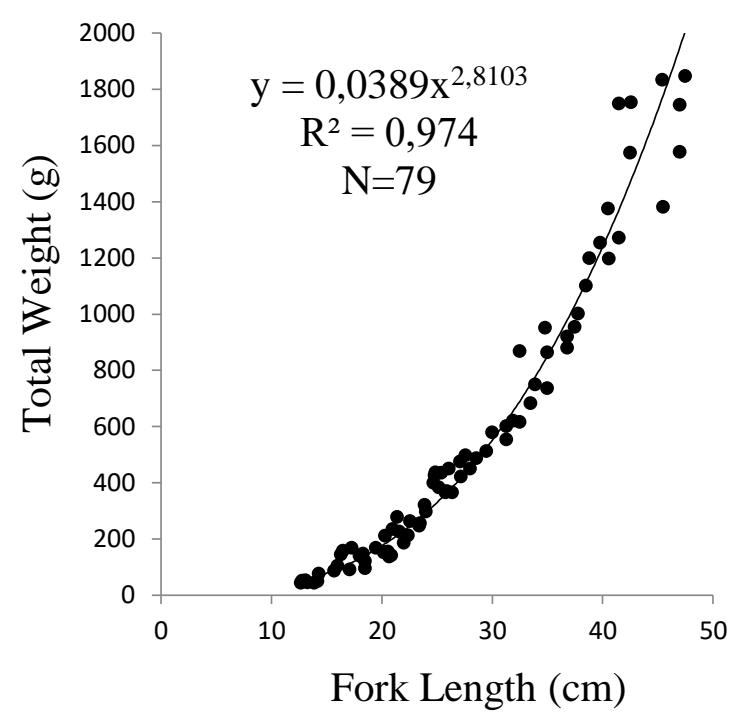

Figure 5. Length-weight relationships of $C$. carpio males from Tercan Dam Lake, Eastern Anatolia, Turkey 
Table 1. Descriptive statistics and estimated parameters of the length-weight relationships for Common carp (C. carpio L., 1758) caughted from Tercan Dam Lake, Eastern Anatolia, Turkey

\begin{tabular}{|c|c|c|c|c|c|c|c|c|c|c|c|}
\hline \multirow{2}{*}{ Sex } & \multirow{2}{*}{$\mathbf{N}$} & \multirow{2}{*}{$\begin{array}{c}\text { FL } \pm \text { SD (cm) } \\
\text { Min.-Mak. }\end{array}$} & \multirow{2}{*}{$\begin{array}{l}\text { W } \pm \text { SD (g) } \\
\text { Min.-Mak. }\end{array}$} & \multicolumn{2}{|c|}{$\begin{array}{l}\text { Regression } \\
\text { parameters }\end{array}$} & \multirow{2}{*}{$95 \% \mathrm{Cl}$ of $\mathrm{b}$} & \multirow{2}{*}{$95 \% \mathrm{Cl}$ of a } & \multirow{2}{*}{ SE (b) } & \multirow{2}{*}{$\mathbf{r}^{2}$} & \multirow{2}{*}{$\begin{array}{c}\mathrm{K} \pm \mathrm{SD} \\
\text { Min.-Mak. }\end{array}$} & \multirow{2}{*}{ GT } \\
\hline & & & & $\mathbf{a}$ & b & & & & & & \\
\hline Male & 111 & $\begin{array}{c}11.2-55.5 \\
(28.3 \pm 1.05)\end{array}$ & $\begin{array}{c}30.2-2860.5 \\
(61.10 \pm 645.73)\end{array}$ & 0.0646 & 2.6613 & -1.314 to -1.076 & 2.581 to 2.748 & 0.042 & 0.9726 & $\begin{array}{l}1.467-3.546 \\
(2.13 \pm 0.04)\end{array}$ & A (-) \\
\hline Female & 79 & $\begin{array}{c}12.7-47.5 \\
(27.3 \pm 1.08)\end{array}$ & $\begin{array}{c}44.6-1846.9 \\
(561.70 \pm 57.36)\end{array}$ & 0.0389 & 2.8103 & -1.567 to -1.263 & 2.707 to 2.921 & 0.053 & 0.9740 & $\begin{array}{l}1.204-4.008 \\
(2.15-0.04)\end{array}$ & A (-) \\
\hline Overall & 190 & $\begin{array}{c}11.2-55.5 \\
(27.9 \pm 0.76)\end{array}$ & $\begin{array}{c}30.2-2860.5 \\
(42.6 \pm 610.79)\end{array}$ & 0.0528 & 2.7202 & -1.371 to -1.183 & 2.654 to 2.786 & 0.033 & 0.9725 & $\begin{array}{l}1.204-4.008 \\
(2.14-0.03)\end{array}$ & A (-) \\
\hline
\end{tabular}

$\mathrm{N}=$ sample size, $\mathrm{FL}=$ fork length $(\mathrm{cm}), \mathrm{W}=$ total weight $(\mathrm{g}), \mathrm{a}=$ intercept, $\mathrm{b}=$ slope, $\mathrm{Cl}=$ confidence intervals, $\mathrm{r}^{2}=$ coefficient of determination, $\mathrm{K}=$ Fulton's condition factor, GT=growth type, A (-)=negatif allometric. 
Table 2. Comparison of the length-weight relationship (LWR) and Fulton's condition factor (K) of previous studies for C.carpio from different habitats

\begin{tabular}{|c|c|c|c|c|c|c|c|c|c|}
\hline Habitat & Sex & $\mathbf{n}$ & $\mathbf{L}_{\min }-\mathbf{L}_{\max }$ & $\mathbf{L}$ & $\mathbf{a}$ & $\mathbf{b}$ & $\mathbf{r}^{2}$ & $\mathbf{K}$ & Source \\
\hline Gelingülü Dam Lake & $\mathrm{C}$ & 407 & $11.7-63.8$ & FL & 0.022 & 3.027 & 0.956 & 2.340 & Kırankaya and Ekmekçi, 2004 \\
\hline Ömerli Dam Lake & $\mathrm{C}$ & 51 & $12.8-84.0$ & $\mathrm{TL}$ & 0.015 & 3.140 & 0.986 & - & Tarkan et al., 2006 \\
\hline Kemer Dam Lake & $\mathrm{C}$ & 92 & $10.9-28.5$ & FL & 0.017 & 3.037 & 0.983 & - & Özcan and Balık, 2007 \\
\hline Almus Dam Lake & M & 237 & $11.8-57.4$ & & 0.073 & 2.600 & - & 1.785 & \\
\hline Hirfanlı Dam Lake & $\mathrm{F}$ & 219 & $12.7-56.3$ & FL & 0.056 & 2.660 & - & 1.712 & Y1lmaz et al., 2007 \\
\hline \multirow[t]{3}{*}{ Koçköprü Dam Lake } & $\mathrm{F}$ & 139 & $12.7-61.7$ & FL & 0.055 & 2.737 & 0.895 & 2.464 & Elp et al., 2008 \\
\hline & $\mathrm{C}$ & 328 & $8.2-61.7$ & & 0.039 & 2.847 & 0.951 & 2.471 & \\
\hline & M & 108 & $17.0-50.8$ & & 0.056 & 2.710 & 0.930 & 1.984 & \\
\hline \multirow[t]{2}{*}{ Apa Dam Lake } & $\mathrm{F}$ & 105 & $16.5-52.5$ & FL & 0.043 & 2.530 & 0.930 & 1.963 & Mert et al., 2008 \\
\hline & $\mathrm{C}$ & 251 & $13.8-52.5$ & & 0.037 & 2.830 & 0.930 & 1.990 & \\
\hline Hirfanlı Dam Lake & M & 65 & $22.9-69.6$ & & 0.042 & 2.778 & 0.990 & - & \\
\hline \multirow[t]{3}{*}{ Altınkaya Dam Lake } & $\mathrm{F}$ & 77 & $21.1-77.6$ & $\mathrm{TL}$ & 0.032 & 2.866 & 0.990 & - & Y1lmaz et al., 2010b \\
\hline & $\mathrm{C}$ & 142 & $21.1-77.6$ & & 0.036 & 2.825 & 0.990 & - & \\
\hline & M & 49 & $36.3-60.00$ & & 0.026 & 2.923 & 0.870 & - & \\
\hline \multirow[t]{2}{*}{ Derbent Dam Lake } & $\mathrm{F}$ & 48 & $16.0-75.0$ & $\mathrm{TL}$ & 0.029 & 2.896 & 0.980 & - & Y1lmaz et al., 2010b \\
\hline & $\mathrm{C}$ & 97 & $16.0-75.0$ & & 0.029 & 2.894 & 0.970 & - & \\
\hline
\end{tabular}


Table 2. (Continued) Comparison of the length-weight relationship (LWR) and Fulton's condition factor (K) of previous studies for C.carpio from different habitats

\begin{tabular}{|c|c|c|c|c|c|c|c|c|c|}
\hline Habitat & Sex & $\mathbf{n}$ & $L_{\text {min-Lmax }}$ & $\mathbf{L}$ & $\mathbf{a}$ & $\mathbf{b}$ & $\mathbf{r}^{2}$ & $\mathbf{K}$ & Source \\
\hline \multirow{3}{*}{ Bayramiç Dam Lake } & $\mathrm{M}$ & 162 & $13.1-42.5$ & \multirow{3}{*}{ FL } & 0.026 & 3.010 & 0.840 & \multirow{3}{*}{2.660} & \multirow{3}{*}{ Çolakoğlu and Akyurt, 2011} \\
\hline & $\mathrm{F}$ & 189 & $12.8-47.9$ & & 0.024 & 3.020 & 0.910 & & \\
\hline & $\mathrm{C}$ & 351 & $12.8-47.9$ & & 0.025 & 3.010 & 0.870 & & \\
\hline \multirow[t]{2}{*}{ Damsa Dam Lake } & $\mathrm{F}$ & 63 & $17.5-69.2$ & \multirow[t]{2}{*}{$\mathrm{TL}$} & 0.018 & 2.966 & 0.915 & 1.572 & \multirow[t]{2}{*}{ Mert and Bulut, 2014} \\
\hline & $\mathrm{C}$ & 160 & $17.1-69.2$ & & 0.021 & 2.900 & 0.900 & 1.580 & \\
\hline \multirow[t]{2}{*}{ Almus Dam Lake } & $\mathrm{C}$ & 31 & $11.0-59.5$ & \multirow[t]{2}{*}{$\mathrm{TL}$} & 0.013 & 3.010 & 0.990 & - & \multirow[t]{2}{*}{ Buhan et al., 2016} \\
\hline & M & 125 & $13.5-59.2$ & & 0.034 & 2.807 & 0.950 & 1.572 & \\
\hline \multirow[t]{3}{*}{ Atatürk Dam Lake } & $\mathrm{F}$ & 106 & $14.6-59.3$ & \multirow[t]{3}{*}{$\mathrm{TL}$} & 0.024 & 2.892 & 0.960 & 1.525 & \multirow[t]{2}{*}{ Yüce et al., 2016} \\
\hline & $\mathrm{C}$ & 231 & $13.5-59.3$ & & 0.029 & 2.847 & 0.950 & - & \\
\hline & M & 55 & $28.7-50.9$ & & - & - & - & 1.392 & \\
\hline
\end{tabular}

Sex: $\mathrm{M}=$ male, $\mathrm{F}=$ female, $\mathrm{C}=$ combined; $\mathrm{n}=$ number of specimens; $\mathrm{L}_{\min }$ and $\mathrm{L}_{\max }:$ minimum and maximum length in sample $(\mathrm{cm}) ; \mathrm{L}: \mathrm{FL}=$ fork length, $\mathrm{TL}=$ total length; $\mathrm{a}=$ intercept; $\mathrm{b}=$ slope value; $\mathrm{r}^{2}=$ coefficient of determination; $\mathrm{K}=$ Fulton's condition factor 


\section{Discussion}

This present study has demonstrated the variations in the LWR and condition factor of the common carp Tercan Dam Lake, Eastern Anatolia, Turkey. The LWR is an important tool that provides information on the growth pattern of fish and to find out whether the fish grows isometrically or allometrically (Tesch, 1968).

The $b$ value of LWR have been used to determine the growth pattern of fish. The value of " $b$ " that expresses length-weight relationship in teleost fishes varies between 2.5 and 3.5 (Ricker, 1975). It differs between the same species according to the sex. Le Cren (1951) reported that females are heavier than the males of the same lengths probably because of the difference in fatness and gonadal development. In addition, it differs under the influence of maturity, seasons, and at different times of day because of the changes in stomach fullness (Arshad et al., 2012).

The value of ' $b$ ' in C.carpio was found to range between 2.6613 to 2.8103 . The highest ' $b$ ' value was arrived in females followed by overall and then males. The exponential value of 2.8103 implies that the female gain weight at a faster rate in relation to the length than males (2.6613) and overall (2.7202). So, the size of female $C$. carpio was bigger and the weight was heavier than males. The " $b$ " value of C.carpio populations living in different localities in Turkey ranged from 2.530 to 3.319 (Table 2).

In this study, "b values were very close to 2.600-2.690 in Hirfanlı Dam Lake (Y1lmaz et al., 2007), 2.690-2.892 in Koçköprü Dam Lake (Elp et al., 2008), 2.530-2.830 in Apa Dam Lake (Mert et al., 2008), 2.778-2.866 in Altınkaya Dam Lake and 2.866-2.923 in Derbent Dam Lake (Y1lmaz et al., 2010b), 2.890 in Hirfanlı Dam Lake (Kirankaya et al., 2014), 2.790 in Marmara Dam Lake (İlhan and Sarı, 2015), 2.807-2.892 in Atatürk Dam Lake (Yüce et al., 2016), but different from 3.027 in Gelingülü Dam Lake
(Kırankaya and Ekmekçi, 2004), 3.140 in Ömerli Dam Lake (Tarkan et al., 2006), 3.037 in Kemer Dam Lake (Özcan and Balık, 2007), 3.319 in Almus Dam Lake (Karataş et al., 2007), 2.900 in Seyhan Dam Lake (Ergüden and Göksu, 2009), 2.943-2.991 in Hirfanl1 Dam Lake (Y1lmaz et al., 2010a), 3.010-3.020 in Bayramiç Dam Lake (Çolakoğlu and Akyurt, 2011), 2.850-2.966 in Damsa Dam Lake (Mert and Bulut, 2014), 3.010 in Almus Dam Lake (Buhan et al., 2016), 2.974 in Gölova Dam Lake (Yüngül et al., 2019).

This differences may be caused by several factors including the seasonal effect, habitat type, degree of stomach fullness, gonad maturity, sex, health, preservation techniques, food availability, and differences in the observed length ranges of the specimen caught (Tesch, 1971).

Fulton's condition factor $(\mathrm{K})$ primarily reflect the state of sexual maturity and the degree of nourishment of fish. The fish having value of more than 1 in condition factor are said to be good in health condition (Nash et al., 2006). In this study, $K$ values were found to be greater than one for C. carpio, therefore it can be an indication that Tercan Dam Lake provide a good habitat for its. These values were higher compared to the results of studies in other regions, except Gelingülü Dam Lake (Kırankaya and Ekmekçi, 2004), Koçköprü Dam Lake (Elp et al., 2008) and Bayramiç Dam Lake (Çolakoğlu and Akyurt, 2011) (see Table 2). The reason may largely be attributed to feeding opportunities.

In conclusion, this study provides the first basic information on length-weight relationships and condition factor of common carp from Tercan Dam Lake. The b values were within the expected range from 2.5 to 3.5 and the $\mathrm{K}$ values was greater than 1 which indicated that the well-being of fish was good. 


\section{References}

Anonim,2020.

http://www.fao.org/fishery/affris/profil-desespeces/common-carp/common-carp-ome/fr/.

Arshad, A., Amın, S.M.N., Nuradiella, Y.L.Z., Cob, Z.C., Ara, R. and Aziz D. 2012. "Population Characteristics of A. japonicus from the Kedah Coastal Waters of Peninsular Malaysia", Journal of Fisheries and Aquatic Science, 7, 162-172.

Bagenal, T.B. and Tesch, F.W., 1978. "Age and Growth. In: Methods for assessment of fish production in freshwaters (ed. T.B. Bagenal)", Blackwell Scientific Publications, Oxford, UK, 101-136.

Buhan, E., Aydın, M., Akın, Ş. and Dal, T. 2016. " Almus Baraj Gölünde Yaşayan 9 Balık Türünün Boy-Ağırlık İlişkisi", Gaziosmanpaşa Üniversitesi Ziraat Fakültesi Dergisi, 33(2), 48-55.

Çolakoğlu, S. and Akyurt, I. 2011. "Bayramiç Baraj Gölü'ndeki (Çanakkale) Aynalı Sazan (Cyprinus carpio L., 1758) Balıklarının Populasyon Yapısı ve Büyüme Özellikleri", Istanbul University Journal of Fisheries and Aquatic Sciences, 26, 27-46.

Dar, S.A., Najar, A.M., Balkhı, M.H., Rather, M.A. and Sharma, R. 2012. "Length Weight Relationship and Relative Condition Factor of Schizopyge esocinus (Heckel, 1838) from Jhelum River, Kashmir", International Journal of Aquatic Science, 3(1), 29-36.

Froese, R. 2006. "Cube Law, Condition Factor and Weight-Length Relationships: History, Meta-Analysis and Recommendations", Journal of Applied Ichthyology, 22, 241-253.

Froese, R., Tsikliras, A.C. and Stergious, K.I. 2011. "Editorial Note on Weight-Length Relations of Fishes", Acta Ichthyologica et Piscatoria, 41, 261-263.

Demirkalp, F.Y. 1992. "Bafra Balık Göllerinde (Balık Gölü-Uzungöl) Yaşayan Sazan (Cyprinus carpio) Balığının Büyüme Özellikleri", Turkish Journal of Zoology, 16, 161-175.
Demirkalp, F.Y. 2007. "Growth Characteristics of Carp (Cyprinus carpio L., 1758) in Liman Lake (Samsun, Turkey)", Hacettepe Journal of Biology and Chemistry, $35,1-8$.

Elp, M., Şen, F. and Çetinkaya, O. 2008. "Some Biological Properties of Carp (Cyprinus carpio L., 1758) Living in Kockopru Dam Lake, Van-Turkey", Journal of Animal and Veterinary Advances, 7, 13241328.

Erguden, S.A. and Goksu, M.Z.L. 2009. "Length-Weight Relationships for 12 Fish Species Caught in Seyhan Dam Lake in Southern Anatolia, Adana, Turkey", Journal of Applied Ichthyology, 25, 501-502.

İlhan, A. and Sarı, H.M. 2015. " LengthWeight Relationships of Fish Species in Marmara Lake,West Anatolia, Turkey", Croatian Journal of Fisheries, 73, 30-32.

Karataş, M., Çiçek, E., Başusta, A. and Başusta, N. 2007. "Age, Growth and Mortality of Common carp (Cyprinus carpio Linneaus, 1758) Population in Almus Dam Lake (Tokat-Turkey)", Journal of Applied Biological Sciences, 1, 81-85.

Kara, A. and Bayhan, B. 2008. "LengthWeight and Length-Length Relationships of the Bogue Boops boops (Linneaus, 1758) in Izmir Bay (Aegean Sea of Turkey)", Belgian Journal of Zoology, 138(2), 154-157.

Kırankaya, Ş. G. ve Ekmekçi, F.G. 2004. "Gelingüllü Baraj Gölünde Yaşayan Aynalı Sazan (Cyprinus carpio L., 1758)'ın Büyüme Özellikleri", Turkish Journal of Veterinary and Animal Sciences, 28, 1057-1064.

Kırankaya, Ş.G., Ekmekçi, F.G., Özdilek, Ş.Y., Yoğurtçuoğlu, B. and Gençoğlu, L. 2014. "Condition, Length-Weight and Length-Length Relationships for Five Fish Species from Hirfanlı Reservoir, Turkey", Journal of FisheriesSciences.com, 8(3), 208213.

Mert, R., Bulut, S. and Solak, K. 2008. "Some Biological Characteristics of Cyprinus carpio (L., 1758) Inhabiting Apa Dam Lake (Konya- 
Turkey)", Afyon Kocatepe Üniversitesi Fen Bilimleri Dergisi, 2, 47-60.

Mert, R. and Bulut, S. 2014. "Some Biological Properties of Carp (Cyprinus carpio L., 1758) Introduced into Damsa Dam Lake, Cappadocia Region, Turkey", Pakistan Journal of Zoology, 46(2), 337-346.

Nash, R.D., Valencia A.H., Geffen, A.J. 2006. "The origin of Fulton's condition factorsetting the record straight", Fisheries, 31(5), 236-238.

Numann, W. 1958. "Limnological and Fisheries Studies on Certain Anatolian Lakes and the Special Analyses about Carp Populations of Living in those Lakes", Istanbul University, Science Faculty, Hydrobiology Research Center, İstanbul, 114.

Özcan, G. and Balık, S. 2007. "Kemer Baraj Gölü’ndeki Cyprinus carpio L., 1758'nun Bazı Biyolojik Özellikleri", Türk Sucul Yaşam Dergisi, 5, 170-175.

Petrakis, G and Stergiou, K.I.1995. "WeightLength Relationships for 33 Fish Species in Greek Waters", Fisheries Research, 21, 465469.

Ricker, W.E. 1975. "Computation and interpretation of biological statistics of fish populations", Bulletin - Fisheries Research Agency, Canada, 1-382.

Sarkar, U.K., Khan, G.E., Dabas, A., Pathak, A.K., MIR, J.I., Robello, S.C., Pal, A. and Singh, S.P. 2012." Length Weight Relationships and Condition Factor of Selected Freshwater Fish Species Found in River Ganga, Gomti and Rapti, India", Journal of Environmental Biology , 34, 951956.

Saylar, Ö. and Benzer, S. 2014. "Age and Growth Characteristics of Carp (Cyprinus carpio L., 1758) in Mogan Lake, Ankara, Turkey", Pakistan Journal of Zoology, 46(5), 1447-1453.

Sokal, R.R. \& Rohlf, F.L. 1987. "Introduction to Biostatistics, 2nd ed.", Freeman, New York, 363.
Tarkan, A.S., Gaygusuz, Ö., Acıpınar, H., Gürsoy, Ç. and Özuluğ, M. 2006. "LengthWeight Relationship of Fishes from the Marmara Region (NW-Turkey)", Journal of Applied Ichthyology, 22, 271-273.

Le Cren, E.D., 1951. "The LenghtRelationship and Seasonal Cycle in Gonad Weight and Condition in the Perch (Perca fluviatilis)", Journal of Animal Ecology, 20, 210-218.

Tesch, F.W. (1968). "Age and Growth. In: Methods for Assessment of Fish Production in Freshwaters, Ricker, W.E. (Ed.)"., Blackwell Scientific Publications, Oxford, 93-123.

Tesch, F.W. (1971). "Age and Growth. In: Methods for Assessment of Fish Production in Fresh Waters, Ricker, W.E. (Ed.)"., Blackwell Scientific Publications, Oxford, 98-103.

Yılmaz, M., Gül, A. and Saylar, Ö. 2007. "Hirfanlı Baraj Gölü (Kırşehir)'nde Yaşayan Cyprinus carpio L., 1758'nun Büyüme Özellikleri", Gazi Üniversitesi, Gazi Ĕgitim Fakültesi Dergisi, 27, 37-57.

Yılmaz, S., Yazıcıŏlu, O., Yılmaz, M. and Polat, N. 2010a. "Hirfanlı Baraj Gölü'nde Yaşayan Cyprinus carpio L., 1758 ve Tinca tinca (L., 1758)'nın Boy-Ağırlık ve Boy-Boy İlişkileri ile Mevsimsel Kondisyon Faktörleri", SDU Journal of Science (EJournal), 5, 154-162.

Yılmaz, S., Polat, N. and Yazıcıoğlu, O. 2010b. "Samsun İli İç Sularında Yaşayan Sazan (Cyprinus carpio L., 1758)'1n BoyAğırlık ve Boy-Boy ilişkileri", Karadeniz Fen Bilimleri Dergisi, 1, 39-47.

Yüce, S., Gündüz, F., Demirkol, F., Çelik, B., Alpaslan, K., Çoban, M.Z., Aydın, R. and Şen, D. 2016. "Atatürk Baraj Gölü'nde Yaşayan Aynalı Sazan (Cyprinus carpio L., 1758)'ın Bazı Populasyon Parametreleri ", Journal of Limnology and Freshwater Fisheries Research, 2(1): 31-42.

Yüngül, M., Gökhan, H.B. and Dörücü, M. 2019. "Gölova Baraj Gölü (Sivas)'nde Yaşayan Pullu Sazan (Cyprinus carpio Linnaeus, 1758)'ın Bazı Büyüme Özellikleri ve Et Veriminin İncelenmesi", International 
Length-Weight Relationships and Fulton's Condition Factor of Common carp (Cyprinus carpio L., 1758) from Tercan Dam Lake, Eastern Anatolia, Turkey

Journal of Pure and Applied Sciences, Zar, J.H. 1996. "Biostatistical Analysis, 3rd 5(1):13-30. ed", Prentice-Hall, Englewood Cliffs, NJ. 662. 